Louisiana State University

LSU Digital Commons

$1-1-2003$

\title{
Zymogram with remazol brilliant blue-labeled Micrococcus lysodeikticus cells for the detection of lysozymes: Example of a new lysozyme activity in Formosan termite defense secretions
}

\author{
Markus Hardt \\ Louisiana State University \\ Youzhong Guo \\ Louisiana State University \\ Gregg Henderson \\ Louisiana State University \\ Roger A. Laine \\ Louisiana State University
}

Follow this and additional works at: https://digitalcommons.Isu.edu/biosci_pubs

\section{Recommended Citation}

Hardt, M., Guo, Y., Henderson, G., \& Laine, R. (2003). Zymogram with remazol brilliant blue-labeled Micrococcus lysodeikticus cells for the detection of lysozymes: Example of a new lysozyme activity in Formosan termite defense secretions. Analytical Biochemistry, 312 (1), 73-76. https://doi.org/10.1016/ S0003-2697(02)00443-8 


\title{
Zymogram with Remazol brilliant blue-labeled Micrococcus lysodeikticus cells for the detection of lysozymes: example of a new lysozyme activity in Formosan termite defense secretions
}

\author{
Markus Hardt, ${ }^{\mathrm{a}}$ Youzhong Guo, ${ }^{\mathrm{a}}$ Gregg Henderson, ${ }^{\mathrm{b}}$ and Roger A. Laine $\mathrm{a}^{\mathrm{a}, \mathrm{b}, \mathrm{c}, *}$ \\ a Department of Biological Sciences, Biochemistry and Molecular Biology Division, Louisiana State University and the LSU Agricultural Center, \\ Baton Rouge, LA 70803, USA \\ ${ }^{\mathrm{b}}$ Department of Entomology, Louisiana State University and the LSU Agricultural Center, Baton Rouge, LA 70803, USA \\ ${ }^{\mathrm{c}}$ Department of Chemistry, Louisiana State University, Baton Rouge, LA 70803, USA
}

Received 14 June 2002

The zymogram method is based on the separation of enzymes by gel electrophoresis and a subsequent enzymatic step, in which the proteins are allowed to renature and relevant enzymes are allowed to catalytically convert substrates that have been either incorporated into the separating gel, sprayed onto the gel, or overlaid within an agarose gel. Zymogram assays have been developed for various enzymes [1]. Zymograms have been extensively used in the detection of lysozymes and other cell wall hydrolases in previous studies [2-4]. Generally, inactivated Micrococcus lysodeikticus (M. luteus is a synonym) cells are trapped in the polymerized polyacrylamide gel as a substrate. Enzymes are separated by electrophoresis under denaturing conditions, which prevent premature interaction of enzyme with substrate. In the following refolding step, enzymes are allowed to renature and hydrolyze the embedded substrate, resulting in clearing zones in otherwise opaque gels. This method permits the simultaneous detection of enzyme activity and estimation of the molecular weight, aiding in the initial identification of the enzyme.

Inactivated $M$. lysodeikticus cells have been traditionally used as a substrate for measuring bacteriolytic activity with a spectrophotometer [5] or in radial diffusion assays (lyso-plate assays) [6]. The common basic principle of these methods lies in the fact that the thick murein layer of bacterial cells forms a turbid suspension, the density of which will be reduced by the activity of a cell wall hydrolase. However sensitivity to experimental

\footnotetext{
${ }^{*}$ Corresponding author. Fax: 225-578-4695.

E-mail address: rlaine@earthlink.net (R.A. Laine).
}

conditions (heterogeneity of the substrate preparation, buffer composition, etc.) compromises the reliability of the assay. For gel-based assays as described herein (lysoplate, zymogram) the limitation lies mainly in the low contrast between clearing zones and background, often requiring additional time-consuming staining/destaining steps, for example with methylene blue [7,8], to identify clearing zones. The present method increases signalto-noise and shortens the total time of the assay.

The photometric suspension assay was improved using $M$. lysodeikticus cells stained with the reactive blue dye Remazol brilliant blue R (RBB) ${ }^{1}$ [9]. RBB has been shown to bind to hydroxyl groups of sugars [10] present in peptidoglycan, the major constituent of bacterial cell walls. Hydrolysis of RBB dye-labeled M. lysodeikticus cells leads to release of soluble blue products and a clearing zone.

Here we present data that whole cells of $M$. lysodeikticus prestained with RBB are an improved substrate for "Lyso"-zymograms, allowing a fast and real-time detection of lysozymes without the need for staining and destaining. We also present data demonstrating the new method used to find lysozyme activity in a protein fraction from the defense secretions of Formosan termites.

\section{Materials and methods}

Materials required for gel preparation, lyophilized cells of $M$. lysodeikticus, chicken egg white lysozyme

\footnotetext{
${ }^{1}$ Abbreviations used: RBB, Remazol brilliant blue; HEWL, chicken egg white lysozyme; MBP, maltose-binding protein.
} 
(HEWL; $14.3 \mathrm{kDa}$ ), bovine serum albumin, Remazol brilliant blue $\mathrm{R}$ and all other reagents were purchased from Sigma Chemical (St. Louis, MO). Chemicals were of reagent grade or better.

\section{Preparation of ostrich lysozyme}

Ostrich eggs were obtained from Three Fork Creek Ostrich Ranch (Pike Corinth, KY). Ostrich lysozyme (20.5 kDa) (a goose-type lysozyme) was purified as described [11].

\section{Preparation of Formosan termite frontal gland secretion}

Defense (frontal gland) secretions were collected from 100 soldier caste termites of the species Coptotermes formosanus. The enlarged head of this termite is $1 / 3$ of the body mass and contains the frontal defense gland, from which the secretion was expressed with tweezers directly into ice-cold phosphate buffered saline. The extract was centrifuged for $5 \mathrm{~min}$ at $10,000 \mathrm{rpm}$ and the insoluble fraction was discarded. The supernatant was filtered through a $0.2 \mu \mathrm{m}$ membrane, and dialyzed (molecular weight cutoff $6-8 \mathrm{kDa}$ ) against deionized water overnight, and subsequently lyophilized. Samples were reconstituted in $50 \mathrm{mM}$ sodium phosphate buffer ( $\mathrm{pH} 7.0)$.

\section{Labeling of $M$. lysodeikticus whole cells with remazol} brilliant blue $R$

M. lysodeikticus whole cells were labeled with the vinyl-sulfone reactive dye RBB according to the procedure for the synthesis of RBB-labeled starch [12] with modifications suggested by Ito et al. [9].

\section{Polyacrylamide gel electrophoresis}

PAGE [13] was performed in $12.5 \%(\mathrm{w} / \mathrm{v})$ polyacrylamide gel $(2.5 \times 8.0 \times 0.75 \mathrm{~cm} 5 \%$ stacking gel and a $5.5 \times 8.0 \times 0.75 \mathrm{~cm}$ separating gel) containing $0.1 \%(\mathrm{w} / \mathrm{v})$ blue $M$. lysodeikticus cells. Polyacrylamide gels and buffers contained $0.1 \%$ (w/v) SDS. Samples were boiled for $2 \mathrm{~min}$ in $2 \times$ sample buffer without reducing agent (62.5 mM Tris, $\mathrm{pH} 6.8,0.006 \%$ (w/v) bromophenol blue as tracking dye, $20 \%(\mathrm{v} / \mathrm{v})$ glycerol, $2 \%(\mathrm{w} / \mathrm{v})$ SDS). Samples of $10 \mu \mathrm{l}$ were used for loading.

Electrophoresis was performed using a Mini Protean II cell (Bio-Rad, Hercules, CA) at a constant $120 \mathrm{~V}$ for $2 \mathrm{~h}$ until the dye front approached the lower gel margin. The gel was washed twice with distilled water for $30 \mathrm{~min}$ to remove SDS, incubated in a covered tray with $300 \mathrm{ml}$ of refolding buffer $\left(50 \mathrm{mM} \mathrm{NaPO}_{4}, \mathrm{pH} 7.0\right.$, containing $1 \%$ (v/v) Triton X-100), and gently shaken at $37^{\circ} \mathrm{C}$.

Standard solutions of HEWL were made in $50 \mathrm{mM}$ potassium phosphate buffer ( $\mathrm{pH}$ 7.0) by serial dilution.
Broad-range prestained protein markers from New England Biolabs (NEB) or Bio-Rad were used as molecular weight standards. The electrophoretic behavior of the standards is slightly affected by the prestaining and the apparent molecular weight is indicated: (NEB prestained protein markers, broad-range) $175 \mathrm{kDa}$; maltose-binding protein (MBP)- $\beta$-galactosidase, $83 \mathrm{kDa}$ $\mathrm{MBP}$-paramyosin, $62 \mathrm{kDa}$ glutamic dehydrogenase, $47.5 \mathrm{kDa}$ aldolase, $32.5 \mathrm{kDa}$ triosephosphate isomerase, $25 \mathrm{kDa} \beta$-lactoglobulin A, $16.5 \mathrm{kDa}$ lysozyme, $6.5 \mathrm{kDa}$ aprotinin; (Bio-Rad prestained SDS-PAGE protein standards, broad range) $208 \mathrm{kDa}$ myosin, $124 \mathrm{kDa} \beta$ galactosidase, $101 \mathrm{kDa}$ bovine serum albumin, $55.4 \mathrm{kDa}$ ovalbumin, $35.7 \mathrm{kDa}$ carbonic anhydrase, $29 \mathrm{kDa}$ soybean trypsin inhibitor, $20.9 \mathrm{kDa}$ lysozyme, $6.7 \mathrm{kDa}$ aprotinin.

Digital images of the gels were taken with the NucleoVision 760 Imaging Workstation (Nucleotech, San Carlos, CA) using a UV transilluminator with a white light converter as light source. The presence of a cell wall hydrolase was detected by the formation of transparent lytic zones in the otherwise opaque bluish gel. The areas of the lytic zones were measured using the ImageQuant software program (Molecular Dynamics (Amersham Biosciences), Sunnyvale CA).

\section{Results and discussion}

Fig. 1 shows zymograms of hen egg white and ostrich egg white lysozyme. Both enzymes were successfully

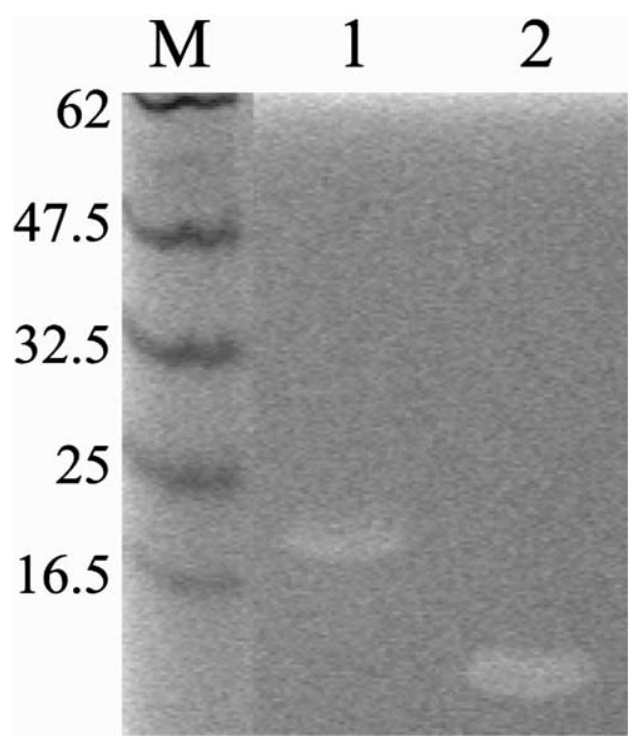

Fig. 1. Zymogram of ostrich egg white lysozyme (lane 1) and hen egg white lysozyme (lane 2). Samples at a concentration of $0.7 \mathrm{mg} / \mathrm{ml}$ were electrophoresed on a $12.5 \%$ SDS-polyacrylamide gel embedded with $0.01 \%$ Remazol blue-labeled M. lysodeikticus whole cells. The gel was incubated in refolding buffer for $12 \mathrm{~h}$. Lane $\mathrm{M}$ contains a prestained protein marker. 
renatured and both solubilized the blue M. lysodeikticus substrate to produce clearing zones. As a negative control bovine serum albumin failed to yield clear spots indicating that the clearing spots are not artifacts of electrophoresis or refolding.

At high enzyme concentrations, clearing zones become visible after as little as $1 \mathrm{~h}$. A detection limit of 0.1 unit of lysozyme $(1.4 \mathrm{ng})$ was observed after $12 \mathrm{~h}$ of incubation. Treatment of the protein samples with a reducing agent prior to electrophoresis had the expected inhibitory effect on renaturation.

After electrophoresis, gels were incubated in refolding buffer to renature proteins. During renaturing incubation enzymes will diffuse in the gel and collide with embedded substrates to form immobilized enzymesubstrate complexes. Hydrolysis of blue-stained $M$. lysodeikticus cells will lead to release of soluble bluelabeled products, and the enzyme will be free to bind to additional substrate sites. Sites of hydrolysis form a readily observable clear reaction zone in a blue-stained gel. The zymogram method can be considered SDSPAGE with a subsequent quasiradial diffusion assay; however, the diffusion is initiated from a band rather than from a point as in radial diffusion. By analogy with radial diffusion assays, the size of the clearing zone will, in part, be determined by the substrate affinity of the enzyme, its catalytic activity, and its diffusion rate and will lower the accuracy of molecular weight estimation. In radial diffusion assays the diameter of the clearing zone is proportional to the logarithm of enzyme concentration applied, a method which has been applied to lysozyme quantification [6].

Fig. 2 shows a zymogram of a dilution series of HEWL. The areas of clearing were measured and a linear relationship to the logarithm of enzyme concentration was found (Fig. 3). An internal standard with known activity is required.

Fig. 4 shows a zymogram of the frontal defense gland secretion of the soldier caste of $C$. formosanus. The clear zone at approximately $14.5 \mathrm{kDa}$ molecular mass shows a novel protein with lysozyme activity as shown by the zymogram (Fig. 4). A Coomassie blue-stained regular SDS gel showed six to nine bands of proteins (data not shown). Lysozymes have not been reported in termite defense gland secretions, although investigators have shown other glycosyl hydrolase activities, such as sucrase, $\alpha$-galactosidase, raffinase, amylase, and cellulase [14] postulated to be present due to the salivary gland evolutionary origin of the defense gland [15]. We do not attribute a defense function to this new lysozyme, but report only its presence.

The herein presented zymogram method allows simultaneous detection and quantitation of multiple distinct enzymes in the same sample, whereas the radial diffusion assay quantifies only total enzyme activity.

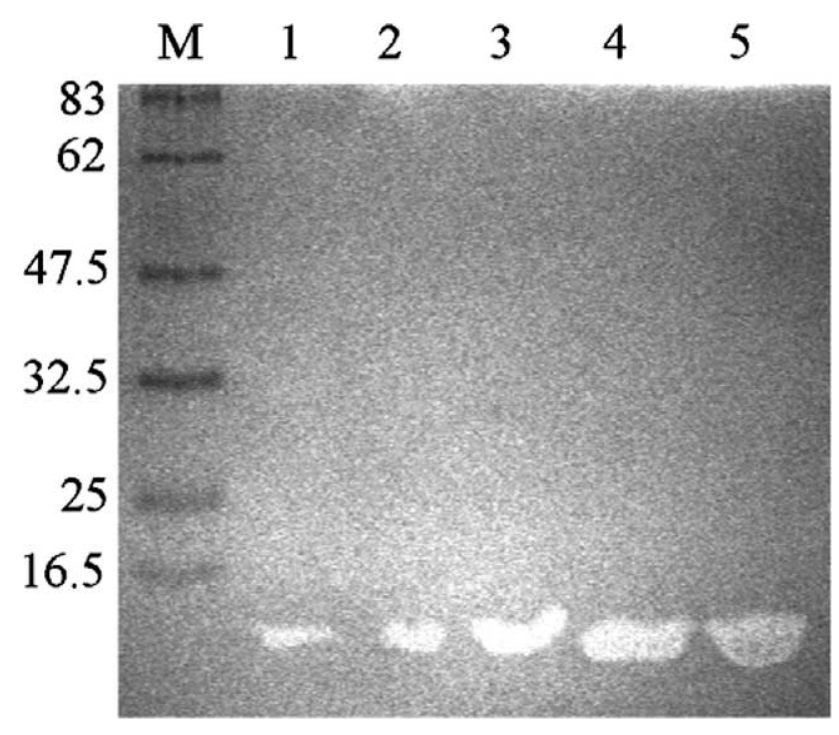

Fig. 2. Zymogram of hen egg white lysozyme. Various amounts of hen egg white lysozyme $(25,50,125,250$, and 500 units per $10 \mu 1$, in lanes $1-$ 5 , respectively) were electrophoresed on a $12.5 \%$ SDS-polyacrylamide gel embedded with $0.01 \%$ Remazol blue-labeled M. lysodeikticus whole cells. The gel was incubated in refolding buffer for $10 \mathrm{~h}$. The amount of lysozyme activity is related to the size of the clearing zone. Lane M contains a prestained protein marker (NEB).

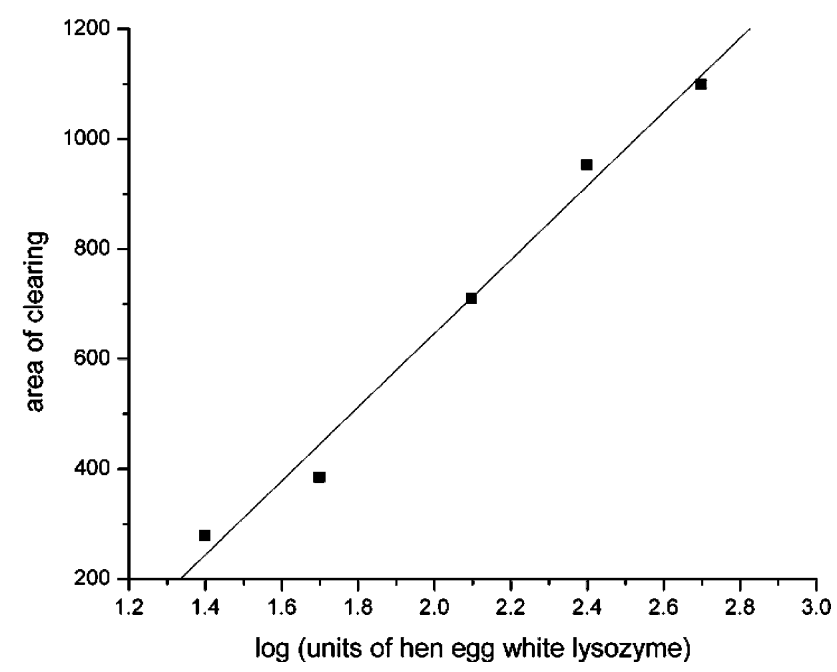

Fig. 3. Semi-logarithmic plot of lysozyme concentration vs the area of clearing zones observed in the gel shown in Fig. 2.

The appearance and detection of clearing zones is improved by the use of dye-labeled $M$. lysodeikticus cells, leading to increased contrast compared to the reduction of opacity with unlabeled cells. Visual monitoring of easily detectable clearing zones in real time allows effortless and constant following of the reaction process, without the requirement for additional timeconsuming staining steps that could disrupt the catalytic reaction.

We are utilizing this technique as a fast and convenient method for the discovery of new lysozymes, as 


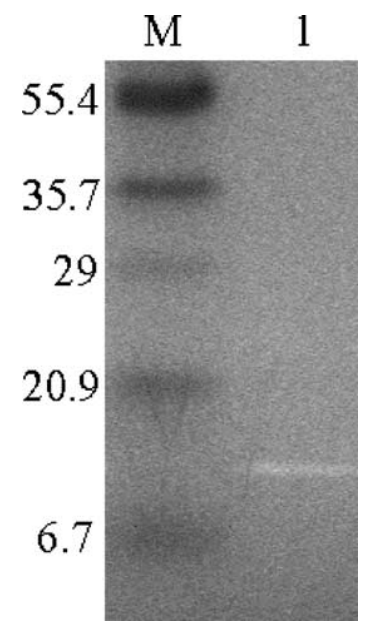

Fig. 4. Zymogram of Formosan termite defense secretion (lane 1) as shown on a $12.5 \%$ SDS-polyacrylamide gel embedded with $0.01 \%$ Remazol blue-labeled M. lysodeikticus whole cells. The gel was incubated in refolding buffer for $10 \mathrm{~h}$. Lane $\mathrm{M}$ contains a broad-range prestained protein marker (Bio-Rad).

demonstrated for the presence of a cell wall hydrolase in the secretion of the Formosan termite frontal gland. This approach may find use in investigations of other cell wall hydrolases, which could include $N$-acetylmuramidases, $N$-acetylglucosaminidases, $N$-acetylmuramyl-L-alanine amidases, endopeptidases, and transglycosylases [16].

\section{Acknowledgments}

We thank Dr. Betty C. R Zhu for the purification of ostrich lysozyme. This project was approved for publication by the Louisiana State University Agricultural Center and Louisiana Agricultural Experiment Station as manuscript 02-26-0616. This work was supported by the Louisiana Educational Quality Support Fund and USDA-ARS.

\section{References}

[1] O. Gabriel, D.M. Gersten, Staining for enzymatic activity after gel electrophoresis, I, Anal. Biochem. 203 (1992) 1-21.

[2] P. Audy, J. Grenier, A. Asselin, Lysozyme activity in animal extracts after sodium dodecyl sulfate-polyacrylamide gel electrophoresis, Comp. Biochem. Physiol. B 92 (1989) 523-527.

[3] D. Leclerc, A. Asselin, Detection of bacterial cell wall hydrolases after denaturing polyacrylamide gel electrophoresis, Can. J. Microbiol. 35 (1989) 749-753.

[4] C. Potvin, D. Leclerc, G. Tremblay, A. Asselin, G. Bellemare, Cloning, sequencing and expression of a Bacillus bacteriolytic enzyme in Escherichia coli, Mol. Gen. Genet. 214 (1988) 241-248.

[5] D. Shugar, The measurement of lysozyme activity and the ultraviolet inactivation of lysozyme, Biochim. Biophys. Acta 8 (1952) 302-309.

[6] E.F. Osserman, D.P. Lawlor, Serum and urinary lysozyme (muramidase) in monocytic and monomyelocytic leukemia, J. Exp. Med. 124 (1966) 921-952.

[7] G. Bernadsky, T.J. Beveridge, A.J. Clarke, Analysis of the sodium dodecyl sulfate-stable peptidoglycan autolysins of select gramnegative pathogens by using renaturing polyacrylamide gel electrophoresis, J. Bacteriol. 176 (1994) 5225-5232.

[8] S.R. Watt, A.J. Clarke, Role of autolysins in the EDTA-induced lysis of Pseudomonas aeruginosa, FEMS Microbiol. Lett. 124 (1994) 113-119.

[9] Y. Ito, H. Yamada, T. Imoto, Colorimetric assay for lysozyme using Micrococcus luteus labeled with a blue dye, Remazol brilliant blue R, as a substrate, Chem. Pharm. Bull. 40 (1992) 1523-1526.

[10] O.A. Stamm, Zur Reaktion von Reaktivfarbstoffen mit Cellulose: II. Natur der Binding, Helv. Chim. Acta. 46 (1963) 3008.

[11] J. Jolles, J.P. Perin, P. Jolles, The ostrich (Struthio camelus) eggwhite lysozyme, Mol. Cell. Biochem. 17 (1977) 39-44.

[12] H. Rinderknecht, P. Widding, B.J. Haverback, A new method for the determination of $\alpha$-amylase, Experientia 23 (1967) 805.

[13] U.K. Laemmli, Cleavage of structural proteins during the assembly of the head of bacteriophage T4, Nature 227 (1970) 680-685.

[14] S. Mishra, Presence of carbohydrases in defensive secretion of soldiers of Odontotermes distans (Holmgren), Indian J. Entomol. 45 (1983) 199-200.

[15] C. Noirot, in: K. Krishna, F.M. Weesner (Eds.), Biology of Termites, vol. I, Academic Press, New York, 1969, pp. 89-123.

[16] J. Ghuysen, D. Tipper, J. Strominger, Enzymes that degrade bacterial cell walls, Methods Enzymol. 8 (1968) 685-699. 